\section{Lembaran} Sejarah
ISSN:

1410-4962
Page

$144-156$

\title{
Dari Mukjizat ke Pemerataan: Kajian Ekonomi Petani Indragiri Hulu 1980-2010
}

\section{ZAIYARDAN ZUBIR}

Universitas Andalas

\begin{abstract}
Indonesian economic development in the Soeharto's New Order brought a miracle and absolute poverty. In the case of Indragiri Hulu's community farmer, that miracle looked up from the massive development oil palm plantation as well as the rapid growth of cities and liveliness of population around the plantation area. While absolute poverty was seen from the deprivation and deforestation of hutan lindung (protected forests), hutan larangan (prohibited forests), hutan adat (customary forests), and hutan ulayat also the expropriation of inhabitan's land without compensation. Moreover, oil palm plantations changed the status of the surrounding community (from landowners to be labourers), eliminated their additional income, then caused bareforests and flood every rainy.
\end{abstract}

\footnotetext{
Abstrak

Pembangunan ekonomi pada masa Orde Baru merupakan suatu kontradiktif antara kemukjizatan dan kemiskinan absolut. Dalam kasus petani masyarakat Indragiri Hulu, Riau, kemukjizatan ekonomi tersebut terlihat dari pembangunan besar-besaran perkebunan kelapa sawit, pertumbuhan kota-kota, dan kesemarakan kehidupan masyarakat di sekitar wilayah perkebunan. Sementara kemiskinan absolut terlihat dari perampasan dan pembabatan hutan lindung, hutan larangan, hutan adat, dan hutan-hutan di tanah ulayat juga pengambialihan lahan penduduk tanpa ganti rugi. Perkebunan kelapa sawit juga mengubah status masyarakat di sekitarnya (dari pemilik lahan menjadi buruh perusahaan perkebunan dengan sistem upah), menghilangkan sumber penghasilan tambahan, serta membuat hutan menjadi gundul dan banjir setiap musim hujan.
}

Keywords: oil palm; New Order; Indragiri Hulu; poverty

Kata kunci: kelapa sawit; Orde Baru; Indragiri Hulu; kemiskinan 


\section{Pengantar}

Keberhasilan pertumbuhan ekonomi dalam skala makro tidak menjamin hal yang sama di tingkat mikro. Bahkan, bisa saja terjadi sebaliknya, di mana pertumbuhan di tingkat makro memperlihatkan hasil yang positif, namun negatif di tingkat mikro. Kontradiktif seperti ini tidak terlepas dari kebijakan negara yang berpihak kepada sekelompok kecil orang (pengusaha) dan menekan sekelompok besar masyarakat (petani). Soedjatmoko dalam Dimensidimensi Kemiskinan Struktural menyebut fenomena ini sebagai sebuah proses kemiskinan struktural, kemiskinan yang disebabkan oleh kebijakan yang tidak berpihak kepada petani, diskriminasi, dualistik, pola ketergantungan yang timpang, dan eksploitasi. Sikap inilah yang dapat memperlebar jurang orang kaya dan miskin. Soedjatmoko juga menambahkan, ketimpanganketimpangan itu meliputi hubungan pusat dengan daerah, hubungan daerah tertentu dengan lainnya, hubungan kota dengan desa, serta hubungan sektor ekonomi modern dengan desa(1984: 48-55).

Ketimpangan ini membuat kondisi pembangunan yang seharusnya meninggikan derajat manusia, justru menjadikan manusia semakin miskin dan terpinggirkan. Sementara pembangunan yang terjadi justru melahirkan dua kutub yang bertolak belakang, yaitu kutub kaya, dengan kekayaan yang melimpah ruah, dan kutub miskin yang hidup dalam kemelaratan sepanjang waktu. Thee Kian Wie (2004: 214, 257) menyebutnya sebagai suatu kontradiktif antara kemukjizatan dan kemiskinan absolut yang berlangsung dalam masyarakat. Dalam konteks ini, ia menggambarkan kemajuan pembangunan Orde Baru seperti sebuah "mukjizat." Pertumbuhan ekonomi Indonesia meningkat sampai dua digit setiap tahun, sehingga untuk pertama kalinya dalam sejarah ekonomi Indonesia modern, ekspor hasil industri dan sektor swasta menjadi mesin utama pertumbuhan industri nasional. Pada periode ini, kemajuan yang dicapai oleh Indonesia mulai menyerupai negaranegara di Asia Timur, baik dalam kinerja ekonomi maupun pertumbuhannya yang pesat.

Senada dengan Thee Kian Wie, ilmuwan Indonesia lainnya, Yahya A. Muhaimin (1980: 272) menyebut fenomena itu sebagai sebuah "keajaiban" dalam pertumbuhan ekonomi Indonesia, yang dilihat dari kemampuan penekanan terhadap lajunya inflasi. Dibandingkan dengan periode sebelum tahun 1966, di mana laju inflasi mencapai 600\% dalam setahun, laju inflasi dalam sepuluh tahun awal masa pemerintahan Orde Baru (1979) dapat ditekan hingga 30\% dan 17,10\% pada tahun 1980 .

Di balik keberhasilan itu, Thee Kian Wie (1980: 7-17) juga memperlihatkan kemunculan kemiskinan absolut dalam masyarakat. Kemiskinan itu disebabkan oleh tidak meratanya pembangunan di Indonesia. Hasil pembangunan lebih banyak dinikmati oleh sekelompok elite, sementara masyarakat kelas bawah hanya mendapatkan cipratannya saja. 
Baik mukjizat maupun kemiskinan absolut tidak lepas dari ekspansi kapitalis. Mukjizat itu lahir sebagai dampak dari kebijakan liberal yang dibuat para teknokrat, terutama untuk penanaman modal swasta, baik penanamam modal asing (PMA) maupun penanaman modal dalam negeri (PMDN). Konsep pembangunan yang dijalankan diikuti dengan kehadiran pemodal-pemodal besar dari berbagai belahan dunia, sehingga muncul zona baru ekonomi Indonesia. Ricard Robison (1986: 373-374), misalnya, menyatakan bahwa kelas kapitalis telah terbentuk di Indonesia sejak akhir 1970-an.

Walaupun telah lahir kelas kapitalis baru, Kunio Yoshihara (1990) dalam Kapitalisme Semu di Asia Tenggara menyatakan bahwa ini masih kapitalisme semu, terutama karena campur tangan pemerintah yang telalu dalam, sementara perkembangan kapitalisme itu sendiri tidak didukung oleh perkembangan teknologi. Padahal, kapitalisme yang murni haruslah lepas dari campur tangan dan harus bergerak di bidang industri bukan perkebunan, sebagaimana yang banyak dikembangkan di Indonesia. Untuk mempertajam kajian tersebut, tulisan ini akan membahas permasalahan kontradiktif itu dengan kasus ekonomi petani masyarakat Indragiri Hulu, Riau.

\section{Ekspansi Kapitalis ke Indragiri Hulu}

Kelapa sawit sudah mulai menjadi primadona sejak awal tahun 1970-an. Sejak tahun 1980-an pemerintah Indonesia bahkan semakin serius menjadikan bisnis ini sebagai sumber pendapatan negara. Melalui perusahaan negara di bawah bendera Perseroan Terbatas Perkebunan Negara (PTPN), pemerintah mengembangkan perkebunan sawit di berbagai pelosok, salah satunya di Indragiri Hulu. Untuk memperlihatkan keseriusan dalam mengelola sawit, pemerintah pusat mengeluarkan Tri Dharma Perkebunan yang bertujuan untuk menciptakan lapangan kerja, meningkatkan pendapatan dan devisa, serta memelihara kelestarian sumber daya alam (Adlin U. Lubis, 1985: 112).

Kebijakan pemerintah Indonesia untuk mengembangkan perkebunan sawit ini sebenarnya merupakan respon kebutuhan dunia terhadap kelapa sawit. Peningkatan kebutuhan kelapa sawit dunia membuat pemerintah membuka lahan-lahan perkebunan baru secara besar-besaran. Tindakan tersebut dilakukan oleh perusahaan negara, perusahaan swasta nasional, sampai perusahaan asing. Pembukaan perkebunan sawit dalam skala besar otomatis membutuhkan tenaga kerja dalam jumlah yang besar pula. Kombinasi kedua faktor itu berimplikasi terhadap peningkatan produksi kelapa sawit secara signifikan. Di tahun 1970, misalnya, produksi sawit di Indonesia hanya 245.000 ton/tahun. Namun, sejak tahun 2006, produksi sawit telah mencapai 20.000.000 ton/tahun dan menjadikan Indonesia sebagai produsen sawit nomor satu di dunia (G. Satari, 2010: 11). 


\begin{tabular}{|c|c|c|}
\hline No & Tahun & Produksi \\
\hline 1 & 1970 & 245.000 ton \\
\hline 2 & 1982 & 900.000 ton \\
\hline 3 & 1984 & 6.000 .000 ton \\
\hline 4 & 2004 & 14.000 .000 ton \\
\hline 6 & 2006 & 20.000 .000 ton \\
\hline 7 & 2010 & 23.000 .000 ton \\
\hline
\end{tabular}

Tabel 1.

Produksi Sawit

Indonesia 1970-2010

(tahun/ton)

Sumber: G. Satari, 2010: 11

Keberhasilan Indonesia sebagai penghasil kelapa sawit memperlihatkan kemajuan besar. Sebuah buku berjudul Direktori Sawit Indonesia (2011) melaporkan bahwa sejak pemerintah memfokuskan kelapa sawit sebagai sektor untuk menyerap tenaga kerja dan sumber pendapatan negara, perkebunan sawit berhasil menyerap tenaga kerja dari berbagai tingkatan sebanyak 8,5 juta orang dan mampu menyumbang devisa untuk negara sebesar US\$ 4,7 milyar ${ }^{1}$.

Angka-angka ini terlihat fantastis sekaligus menyimpan sejumlah persoalan dengan masyarakat setempat dan ancaman kerusakan lingkungan. Sebut saja masalah kebakaran hutan, di mana Indragiri Hulu khususnya dan Riau pada umumnya "mengekspor" kabut asap hingga ke negera-negara tetangga seperti Singapura dan Malaysia. Menghadapi kasus seperti ini, biasanya pihak perusahaan mengkambinghitamkan masyarakat sebagai penyebab kabut asap. Hal ini sebagaimana dilakukan oleh PT Tesso Indah, yang segera dibalas oleh Fajar Restu Hadi, anggota Dewan Perwakilan Rakyat Daerah (DPRD) Indragiri Hulu (Riau Mandiri, 29 Februari 2008: 3).

Sementara itu, untuk memberi kesempatan pada masyarakat terlibat dalam perkebunan sawit, pemerintah membuat program yang dinamakan Perkebunan Inti Rakyat (PIR). Program ini dikaitkan dengan program transmigrasi sehingga melahirkan program PIR-Transmigrasi yang ditujukan sebagai upaya pengentasan kemiskinan. Program selanjutnya adalah Perkebunan Besar Swasta Nasional (PBSN) I (1981-1986), PBSN II (1986-1989), dan PBSN III (1989-1992). Selanjutnya, pada masa Reformasi, berdasarkan Surat Keputusan Menteri Pertanian No. 26/2007, pemerintah tidak memperkenankan bagi perusahaan besar memiliki $100 \%$ area perkebunan sawit. Sebanyak 20\% harus disisakan untuk pembangunan

1) Walaupun semua keuntungan itu ada benarnya juga, namun yang menikmati adalah para pemilik perkebunan besar, raja-raja sawit yang menguasai perkebunan besar sawit di Indonesia, seperti Bimoli, PT Bakrie Sumatera Plantation, PTPN XIII, PT Sampoerna Agro. Sisi negatif dari kehadiran perkebunan besar diabaikan seperti nasib buruh dan petani yang tanahnya dirampas untuk perkebunan sawit. Bahkan, satu fakta pun tidak menyebutkan tentang nasib yang dialami petani dalam buku tersebut. 
PIR (Herman Hidayat, 2008)². Dalam praktiknya, peraturan ini diselewengkan oleh pengusaha, sehingga tetap saja merugikan masyarakat (Riau Mandiri, 9 September 2003: 31; Riau Mandiri, 20 Desember 2003: 31)³.

Pada awalnya, program ini tidak memperlihatkan kemajuan bagi para warga transmigran. Loekman Sutrisno (1997) bahkan melihat program tersebut sebagai program penyebaran kemiskinan dari kantong-kantong kemiskinan di Pulau Jawa ke Luar Jawa. Artinya, jika sebelumnya yang miskin hanya pulau Jawa, setelah mereka bermigrasi, kehidupan mereka di daerah tujuan juga tidak baik sehingga mereka tetap saja miskin. Namun, sejak tahun 1998-an, perubahan besar terjadi di kalangan petani sawit. Mereka yang miskin sepanjang rezim Orde Baru kemudian mengalami kemajuan ekonomi, terutama yang berkaitan dengan program PIRTransmigrasi. Hal ini terjadinya karena ada peningkatan harga kelapa sawit dunia, seiring melemahnya nilai tukar rupiah terhadap dolar (wawancara dengan Noer Hadianto di Sei Lalak).

Perhatian pemerintah untuk ekstensifikasi kelapa sawit berlangsung sejak Pelita IV. Sejak saat itu, pemerintah mulai berencana mengembangkan kelapa sawit secara besar-besaran. Langkah awalnya adalah pembukaan perkebunan kelapa sawit baru seluas 911.511 hektare di berbagai provinsi di Indonesia. Setidaknya ada sebanyak tiga belas provinsi yang disasar pemerintah pusat untuk dijadikan wilayah uji coba. Dari luas perkebunan tersebut, Provinsi Riau menjadi wilayah pengembangan perkebunan sawit terluas, yaitu 266.300 hektare (Sumardiko, 1985: 149). Jumlah ini hampir mencapai 25\% dari keseluruhan rencana pengembangan kelapa sawit di Indonesia (lihat Tabel 2).

Kebijakan pemerintah pusat itu memperlihatkan bahwa Provinsi Riau dicanangkan sebagai salah satu pusat perkebunan sawit. Pertanyaannya ialah mengapa Riau? Jawabannya terletak pada potensi besar yang dimiliki oleh provinsi ini untuk dijadikan lahan perkebunan kelapa sawit dalam skala besar-besaran. Potensi yang dimaksud ialah ketersediaan lahan yang sangat luas dan belum digarap. Selain itu, setidaknya masih terdapat hutan dan rimba yang bisa dijadikan perkebunan sawit.

2) Eksploitasi hutan besar-besaran dalam skala nasional telah berlangsung sejak awal Orde Baru dengan jalan mengambil kayu maupun membuka perkebunan dengan suntikan dana dari para investor. Pada tahun 1993, pemerintah menambah area perkebunan sawit menjadi 912.000 hektare.

3) Dalam kasus dengan PTPN V di Kecamatan Peranap misalnya di mana sertifikat tanah masyarakat dipegang oleh PTPN V, terutama untuk perkebunan yang telah beroperasi di Bukit Selasih. Menurut direksi PTPN V, jumlah tanah masyarakat yang telah memiliki sertifikat di Bukit Selasih adalah 1.850, di Binio 1.250, di Pandan Wangi 1.684. Raja Nasution, Direksi PTPN V, menyatakan bahwa sertifikat tanah telah dikembalikan kepada masyarakat. Sekarang hanya tinggal 260 sertifikat yang belum diserahkan, tetapi masyarakat tidak pernah menerima sertifikat itu sehingga mereka menuding PTPN V telah berbohong. 


\begin{tabular}{|c|c|c|}
\hline No & Provinsi & Luas \\
\hline 1 & Aceh & 14.500 \\
\hline 2 & Sumatera Utara & 59.222 \\
\hline 3 & Riau & 266.300 \\
\hline 4 & Sumatera Barat & 16.650 \\
\hline 5 & Jambi & 113.500 \\
\hline 6 & Bengkulu & 5.500 \\
\hline 7 & Sumatera Selatan & 79.910 \\
\hline 8 & Jawa Barat & 6.211 \\
\hline 9 & Kalimantan Barat & 122.530 \\
\hline 10 & Kalimantan Timur & 25.798 \\
\hline 11 & Sulawesi Selatan & 8.230 \\
\hline 12 & Irian Jaya & 47.000 \\
\hline 13 & P.M. & 150.000 \\
\hline & Jumlah & $\mathbf{9 1 1 . 5 1 1}$ \\
\hline
\end{tabular}

Tabel 2.

Pengembangan Kelapa

Sawit 1982-1987 di

Indonesia (dalam

hektare)

Sumber: Sumardiko,

1985: 149.

Hanya saja, para pengusaha lupa bahwa dalam aturan adat masyarakat lokal semuanya itu sudah ada aturannya. Misalnya saja, rimba yang dianggap tidak bertuan oleh penguasa dan pengusaha, sesungguhnya telah diperuntukkan sebagai hutan lindung dan dikeramatkan oleh masyarakat Talang Mamak (Antara Pekanbaru, 28 Februari 2010) ${ }^{4}$. Pola ini sebenarnya tidak lebih dari sekadar bentuk perampasan tanah milik rakyat. Tanah yang sejatinya memiliki kekuatan hukum adat, dirampas atau dimiliki oleh penguasa dan pengusaha (Suhartono W. Pranoto, 2001: 8) ${ }^{5}$.

Baik pihak pemerintah maupun pihak swasta seperti mengabaikan kepemilikan tanah etnis Talang Mamak tersebut dan tetap menggarapnya untuk perkebunan sawit, baik oleh investor nasional, investor asing, bahkan pendatang dari luar Indragiri Hulu, terutama etnis Batak dan Jawa. Kondisi demikian membuat masyarakat Talang Mamak semakin terjepit

4) Patih Laman, kepala suku etnis Talang Mamak menyatakan bahwa hutan adat yang sudah diakui pemerintah Kabupaten Indragiri Hulu melalui Surat Keputusan Bersama (SKB) Nomor 31/SKB/II/2007 dan Nomor 180/HK/II/2007 seluas 1.800 hektare. Namun, peraturan tersebut tidak diakui investor dan mereka tetap menjadikanya sebagai lahan sawit. Hingga kini ada sedikitnya 1.904 hektare hutan adat masyarakat Talang Mamak habis dibabat oleh para pendatang dalam tempo dua tahun terakhir sehingga menyebabkan dua di antara empat kawasan hutan adat telah beralih fungsi menjadi perkebunan sawit. Kedua hutan adat tersebut yakni Hutan Keramat Rimba Puaka Penyabungan dan Penguanan seluas 1.800 hektare, kemudian Hutan Keramat Rimba Puaka Sungai Tunu seluas 104.933 hektare. Adapun yang masih tersisa hanya Hutan Keramat Rimba Puaka Durian Bejajar seluas 98.577 hektare dan Hutan Keramat Rimba Puaka Kelumbuk Tinggi Baner seluas 21.901 hektare.

5) Dalam bahasa Suhartono dikatakan dengan istilah anglempit bumi. 
dan terkepung oleh perkebunan besar. Keterpojokan mereka semakin tergambar jelas dengan beroperasinya lima perusahaan besar nasional yang menanamkan modalnya di sana, yaitu PT Medco Energi Internasional, PT Kencana Amal Tani (KAT) dan PT Banyu Bening Utama, PT Alam Sari Lestari (ASL), serta PT Wahana Mandiri Indonesia (Betty Tiominar, 2011: 24-40).

Kehidupan merekapun mengalami perubahan besar; dari bertani atau agraris menjadi buruh di perkebunan sawit. Kondisi demikian sebagaimana gambaran Suhartono, bahwa dalam ekonomi agraris yang bertransisi ke ekonomi kapitalis agraris, posisi petani direduksi menjadi tenaga kerja setelah garapan mereka dicaplok. Petani yang hidup di bawah subsistensi menjadi semakin tergantung kepada patronnya (Suhartono W. Pranoto, 2001: 204). Artinya, kemandirian yang dimiliki petani selama ini menjadi hilang dengan masuknya kapitalis ke desa-desa seperti yang dilakukan PTPN V (Riau Mandiri, 18 Mei 2005: 17) .

Untuk wilayah Riau umumnya dan Indragiri Hulu khususnya, PTPN V diberi tanggung jawab penuh oleh pemerintah pusat untuk pengembangan perkebunan karet dan kelapa sawit(wawancara dengan Rasiman di Sei Lalak, 11 April 2012). Untuk tahap awal, PTPN V membuka perkebunan di beberapa tempat, seperti di Sungai Parit, Sei Lalak, dan Bunio di Indragiri Hulu (wawancara dengan Musa di Sungai Parit 15 April 2012 dan Sahar di Se Lalak, 11 April 2012) ${ }^{7}$. Sebagai perusahaan milik negara, pembukaan lahan ini sebenarnya mewarisi persoalan besar yang dibuat oleh PTPN V sehingga menuai konflik dengan masyarakat di kemudian hari. Konflik yang tidak kunjung henti itu terutama menyangkut masalah perampasan tanah yang dilakukan oleh PTPN V (FN News, 7 Oktober 2010; Riau Mandiri, 9 September 2003) $)^{8}$.

Berdasarkan pemikiran itulah, pemerintah pusat mulai berusaha untuk mengembangkan kelapa sawit di Indragiri Hulu dengan empat pola. Pertama, secara swadaya oleh Dinas Perkebunan seluas 75.066,95 hektare dan swadaya murni masyarakat seluas $67.452,70$ hektare untuk perkebunan

6) Ketidakjelasan sikap PTPN V tentang tanah rakyat yang mereka caplok itu menjadi persoalan panjang. Pada tahun 1978-an, masyarakat memang tidak bisa menuntut banyak. Namun, sejak reformasi, tanah masyarakat yang dicaplok, seluas 1.771,8 hektare, mulai dituntut kembali oleh masyarakat. Walaupun sudah berulang kali didemo bahkan sudah dibahas sampai pada tingkat DPRD Provinsi Riau, tetapi tidak ada titik terangnya karena PTPN V tidak mengakui melakukan pencaplokan.

7) Pembukaan perkebunan besar milik negara di desa Sungai Parit kecamatan Pasir Penyu dan Sei Lalak sudah dikerjakan sejak tahun 1979. Namun, untuk daerah lain seperti Buni, baru dilaksanakan setelah tahun 1985.

8) Dalam setiap wilayah yang memiliki perkebunan, PTPN V tidak pernah tidak luput dari permasalahan. Persoalan dasar adalah perampasan tanah yang mereka lakukan sehingga merugikan masyarakat lokal. Pola-pola seperti ini telah menjadi model kerja yang dilakukan oleh PTPN V di Indragiri Hulu Riau, sehingga mendapat perlawanan dari masyarakat. 
karet, kelapa sawit, kelapa hibrida, cokelat, kopi, pala, cabe, enau, dan lainlain. Kedua, melalui Unit Pelayanan Pengembangan (UPP) dengan luas 3.813 hektare terdiri dari kebun karet rakyat seluas 3.739 hektare dan kebun kopi rakyat seluas 74 hektare. Ketiga, perkebunan besar swasta atau Badan Usaha Milik Negara (BUMN) seluas 55.706,66 hektare, terdiri dari perkebunan karet seluas 2.745 hektare dan kebun kelapa sawit seluas 52.960,66 hektare. Terakhir, perkebunan melalui pola PIR seluas 41.025 hektare, terdiri dari plasma karet seluas 11.349 hektare dan plasma kelapa sawit seluas 29.676 hektare (Biro Pusat Statistik, 2008).

Keempat pola pengembangan di atas sudah berlangsung sejak awal Orde Baru. Secara nasional, program ini menjadi ikon bagi pemerintah untuk meningkatkan devisa dan membuka lapangan pekerjaan baru. Tidak mengherankan dalam tiga puluh tahun belakangan, Indragiri Hulu pun mengalami pertumbuhan ekonomi pesat, ditandai dengan kehadiran berbagai perusahaan perkebunan besar seperti PTPN V, PT KAT, PT Lembah Subur, PT Tunggal, PT Astra Argo Lestari Grup, PT Banyu Bening Utama dan PT Regunas Agri Utama, PT Asian Agri, PT Duta Palma, PT Bertuah Aneka Yasa, PT Inecda, PT. Tunggal Perkasa Plantation, PT. Bintang Riau Sejahtera, PT. Gandhaerah Hendana, serta Pelangi Nusantara. Adapun perusahaan asing yang menanamkan investasinya di sektor perkebunan sawit adalah PT ASL dan PT Wilmar (LSM Scale Up, 2007; DPD APKASINDO Kabupaten Indagiri Hulu, 2014) ${ }^{9}$. Hingga tahun 1994, luas keseluruhan perkebunan itu mencapai 475.000 hektare (Bapeda dan Kantor Statistik Kabupaten Indragiri Hulu, 1995: 167) ${ }^{10}$. Perluasan itu digunakan sebagai perkebunan sawit milik pemerintah, swasta dan asing ${ }^{11}$. Apabila ditotal, jumlah perkebunan besar mencapai empat puluh tujuh.

Ledakan dari sektor kelapa sawit ternyata tidak dapat dinikmati secara merata oleh masyarakat asli di Indragiri Hulu. Ambisi besar pemerintah pusat di bawah kendali Presiden Soeharto yang menjadikan Indonesia sebagai penghasil sawit terbesar di dunia (Marcus Colchester dan Sophie Chao, 2011: 22-23) ${ }^{12}$ tersebut hanya dinikmati oleh para investor, sementara

9) PT Wilmar merupakan perkebunan sawit milik etnis Cina dari Malaysia.

10) Sebelum masuknya perkebunan besar, baik milik negara maupun swasta, hanya ada satu perkebunan besar di Indragiri Hulu, yaitu PTPN dengan lokasi perkebunan yang terletak di Sungai Parit dan Lalak. Luasnya pun tidak mencapai 1.000 hektare.

11) Laporan ini memang tidak menerangkan secara rinci wilayah setiap perkebunan besar yang dibuka. Namun, penambahan setiap tahunnya memperlihatkan adanya lahan-lahan baru yang dibuka. Pada tahun 1976, perkebunan kelapa sawit belum tercatat dalam data-data resmi pemerintah di Indragiri Hulu. Perkebunan yang dominan adalah perkebunan karet rakyat, kayu manis, cengkeh, kopi, kelapa, pala, dan pinang. Namun, berdasarkan data tahun 1997, kelapa sawit menjelma sebagai sektor produktif, yaitu 27.441 hektare. Dari segi produksi, perkebunan sawit mencapai 192.407 ton, sedangkan karet rakyat 84.803 ton. Bandingkan Biro Pusat Statistik (1976, 1998).

12) Sampai tahun 2010, lahan kelapa sawit Indonesia terhitung paling luas di dunia, 
penduduk asli tetap saja hidup merana dalam kemiskinannya ${ }^{13}$. Hal itu diperburuk dengan munculnya kebiasaan menjual tanah kepada pendatang, baik etnis Batak maupun Jawa ${ }^{14}$ di kalangan penduduk asli belakangan ini (Betty Tiominar, 2011: 39).

\section{Jeritan Petani di Perkebunan Sawit}

Sejak kehadiran modal besar, berbagai perubahan terjadi dalam kehidupan masyarakat Indragiri Hulu. Perubahan itu meliputi orientasi kerja baru seperti menjadi buruh di perusahaan perkebunan. Walaupun menjadi buruh sebenarnya tidak terlalu aneh dan asing, namun mereka tidak terbiasa dengan jadwal kerja yang ketat, target kerja yang jelas, dan upah yang terbatas, sehingga menimbulkan persoalan. Di lain sisi, masuknya perkebunan besar juga membuat pemilik perkebunan menjadi buruh tebang, tanam, pemelihara, sampai panen dengan sistem upah.

Salah satu perusahaan yang banyak mempekerjakan tenaga kerja lokal adalah PTPN V yang memiliki perkebunan dekat dengan perkampungan. $\mathrm{Hal}$ ini bisa dipahami karena wilayah perkebunan besar milik PTPN V itu adalah bekas kebun-kebun rakyat di sekeliling kampung mereka. Pilihan bekerja sebagai buruh kebun seperti ini seperti mendapat mainan baru bagi masyarakat, terutama muda-mudi ${ }^{15}$. Di lain sisi, upah tunai yang mereka dapatkan setiap bulannya membuat mereka bisa memegang uang kontan yang dapat dibelanjakan. Dengan setengah bergurau pula, para buruh PTPN $\mathrm{V}$-yang berkembang di Indragiri Hulu karena mendapat suntikan modal dari Bank Dunia- ini menyebut diri mereka sebagai "pegawai Bank Dunia."

yaitu 9,4 juta hektare. Malaysia berada di urutan kedua dengan 4,6 juta hektare. Pola yang diterapkan di Indonesia adalah sewa yang dimediasi negara untuk perkebunan besar di atas tanah negara. Petani plasma menempati $40 \%$ dari total luasan, setengah dalam skema yang dikaitkan dengan perkebunan dan setengah lagi mandiri.

13) Di beberapa tempat seperti satuan pemukiman (SP) 1, SP 2, dan SP 3 Lalak, pendatang yang memiliki PIR atau plasma memang terlihat lebih makmur dibandingkan dengan penduduk asli. Wawancara dengan Ismanto di SP 2 Sei Lalak, 12 April 2012.

14) Di beberapa pelosok pedesaan seperti Pitonggan, Dusun Tuo, etnis Batak dan Jawa telah memiliki kebun-kebun sawit sendiri yang mereka beli atau dapatkan dari masyarakat setempat. Mereka membelinya dari penduduk asli. Bentuk lain yang terjadi adalah perkawinan antara pendatang dengan penduduk asli kemudian pendatang itu diberi tanah untuk dijadikan kelapa sawit oleh mertuanya seperti dalam kasus Sirait yang pada awalnya berprofesi sebagai tukang kredit. Wawancara dengan Sirait di Pitonggan dan Manurung di Dusun Tuo 17 April 2012.

15) Muda-mudi tertarik bekerja sebagai buruh karena di arena perkebunan itulah mereka bisa berdekatan untuk waktu yang lama. Upah yang rendah dan jam kerja yang panjang tidak menjadi persoalan bagi mereka. Kebutuhan bisa berduaan membuat mereka mau mengambil pekerjaan sebagai buruh perkebunan besar itu. Tidak mengherankan jika di atas truk sempit yang memberangkatkan mereka, keceriaan dan kegembiraan senantiasa terpancar, seperti orang pergi ke taman hiburan. Wawancara dengan Ikhsan di Kota Medan 19 April 2012 dan Aulia di Silanjuik 19 April 2012. 
Sekitar jam 06.00 pagi, di bulan Desember 1995 lalu, sebuah truk Fuso memasuki desa Kota Medan, sebuah desa terpencil di pedalaman Kabupaten Indragiri Hulu Riau untuk menjemput penumpang langganannya. Satu per satu penduduk menaiki Fuso itu dan jumlahnya mencapai 150-200 orang. Menjelang jam 07.00, setelah penumpang semua penumpang naik maka truk itupun menuju lokasi kerja, yang letaknya berkisar tujuh sampai sepuluh kilometer dari kampung mereka. Masyarakat setempat menyebut diri mereka sebagai "pegawai bank dunia" (Zaiyardam Zubir, 2002: 1-2).

Kebutuhan buruh membuat perusahaan ada kalanya memaksa penduduk lokal untuk menjadi tenaga kerja. Hal ini sebagaimana terjadi pada masyarakat Talang Mamak. Setelah tanah mereka dirampas, kaum muda dipaksa menjadi buruh perkebunan sawit.

Ketika saya penelitian tahun 1998-1999, saya melihat langsung penduduk desa etnis Talang Mamak dipaksa mengubah cara hidupnya. Warga desa lanjut usia sering mengekspresikan kenangan mereka mengenai perladangan di masa lalu, sedangkan warga desa yang masih muda, sekarang bekerja sebagai buruh di perkebunan kelapa sawit terdekat (Yoon Hee Kang, 2005: 37).

Persoalan tenaga kerja lokal yang terdidik di Riau muncul sejak dikembangkannya kerja sama Sijori. Masyarakat Riau tidak mau menerima begitu saja lowongan kerja yang ada. Mereka cenderung memilih-milih pekerjaan, pilihan yang seringkali tidak rasional karena tidak didukung oleh kemampuan kerja dan pengalaman (Suara Pembaharuan, 7 Januari 1993). Dalam kondisi yang demikian, penempatan mereka sebagai buruh kasar tentu saja menjadi pilihan yang tidak bisa dielakkan karena rendahnya kualitas kemampuan yang mereka miliki. Tanpa pendidikan yang memadai dan pengalaman kerja sebagai petani, mereka tidak punya pilihan lain kecuali menjadi buruh kasar di perkebunan besar (Sinar Pagi, 19 Januari 1993).

Selain masyarakat yang bekerja di perusahaan perkebunan sawit, kehidupan masyarakat setempat juga tidak kalah susahnya. Kesusahan mereka disebabkan oleh ketiadaan penghasilan tambahan. Mereka yang selama ini menggantungkan tambahan pendapatan dari hasil hutan seperti kayu, damar, rotan, dan buah-buahan, kehilangan sumber daya tersebut karena dijadikan perkebunan (Riau Mandiri, 26 September 2001). Hutan juga menjadi gundul dan menyebabkan banjir setiap musim hujan. Masyarakat kelas bawah paling dirugikan karena banjir menyapu bersih 652 hektare perkebunan rakyat juga padi dan palawija seluas 1.522 hektare (wawancara dengan Ibrahim di Sungai Parit, 15 April 2012 dan Riau Mandiri, 16 April 2003). 
Nasib serupa dialami oleh etnis Talang Mamak. Etnis ini kondisinya lebih parah, karena dalam berbagai perjanjian yang dibuat, mereka seringkali ditipu. Bagi etnis Talang Mamak, perjanjian yang bersifat tertulis itu sama saja dengan perjanjian lisan. Mereka juga mau begitu saja memberikan cap jempol mereka dalam setiap kontrak yang diberikan para penguasa dan pengusaha bekerja sama dengan kepala desa karena buta huruf. Hal ini sebagaimana ditulis Peter L. Berger dalam Piramida Kurban Manusia: Etika Politik dan Perubahan Sosial (1982), "kami adalah kaum terbelakang, tidak berpendidikan dan buta huruf, sehingga membuat kami dengan mudah disingkirkan oleh pengusaha besar."

\section{Penutup}

Pembangunan di Indragiri Hulu berkembang secara signifikan. Perkebunan besar bermunculan di berbagai tempat, kota-kota tumbuh dan berkembang di pinggiran perkebunan, sementara pasar malam di wilayah perkebunan berlangsung secara rutin, sebagaimana zaman kolonial Belanda. Namun, di balik itu semua, ada persoalan mendasar dengan para petani terkait ganti rugi hak atas tanah yang dirampas perkebunan besar. Para investor seringkali mengabaikan kearifan lokal seperti hutan lindung, hutan larangan, hutan adat, dan tanah ulayat serta merampas dan membabat hutan tanpa ganti rugi. Kalaupun membayar, jumlahnya kerap kali kecil dan dilakukan dengan memberi sogokan kepada pemerintah, mulai tingkat desa, kecamatan, kabupaten, provinsi, sampai para petinggi di Jakarta.

Pada akhirnya, mukjizat dan pemerataan di Indragiri Hulu sejatinya merupakan dua hal yang bertolak belakang. Mukjizat hanya diperoleh oleh sekelompok orang seperti investor dan penguasa, sedangkan pemerataan tidak berjalan sebagaimana mestinya. Untuk kalangan bawah, alih-alih pemerataan, kemiskinan absolutlah yang justru harus mereka terima. Dengan demikian, tepat sekali judul buku yang ditulis oleh Mamadou Cissokho, God is not a Peasant (2009), di mana petani seperti dihalalkan untuk ditindas karena Tuhan sendiri bukan berasal dari kelompok mereka.

\section{Referensi}

Adlin U. Lubis (1985). "Pasang Surut Perkembangan Perkebunan dan Produksi Kelapa Sawit di Indonesia Sebelum Perang sampai Pelita II serta Permasalahannya," dalam Proceding Simposium Kelapa Sawit di Medan 2728 Maret 1985.

Said Husein Alatas (1988). Mitos Pribumi Malas: Citra Orang Jawa, Melayu dan Filipina Dalam Kapitalisme Perkebunan. Jakarta: LP3S.

Bambang Purwanto. "Sejarah Ekonomi Desa: Antara eksploitasi dan kesempatan", Dinamika Pedesaan dan Kawasan UGM Yogyakarta. No. 1/01/2001.

Berger, Peter L (1982). Piramida Kurban Manusia: Etika Politik dan Perubahan Sosial. 
Jakarta: LP3ES.

Betty Tiominar (2011). Perkebunan dan Kemiskinan: Kisah Sebuah Kampung di Kawasan Perkebunan Kelapa Sawit. Jakarta: Down to Earth.

Breman, Jan (1997). Menjinakkan Sang Kuli, Politik Kolonial pada Awal Abad ke-20. Jakarta: Grafiti.

Biro Pusat Statistik (1976). Riau Dalam Angka 1976. Pekanbaru: Biro Pusat Statistik. (1978). Riau Dalam Angka 1978. Pekanbaru: Biro Pusat Statistik. (2008). Riau Dalam Angka, 2007. Pekanbaru: Biro Pusat Statistik.

Cissokho, Mamadou (2009). God is not a Peasant. Precence Africaine et Grad.

Colchester, Marcus dan Sophie Chao (eds) (2011). Ekspansi Kelapa Sawit di Asia Tenggara: Kecenderungan dan implikasi bagi masyarakat lokal dan masyarakat adat. Bogor: Perkumpulan Sawit Watch.

Masyarakat Perkelapa Sawitan Indonesia (2011). Direktori Sawit Indonesia. Jakarta: Masyarakat Perkelapa Sawitan Indonesia,

DPD APKASINDO Kabupaten Indagiri Hulu (2014). Daftar Perusahaan Perkebunan dan Pabrik Pengolahan Kelapa Sawit. Rengat: DPD APKASINDO Kabupaten Indragiri Hulu.

Dwi Wulan Pujiriyani (dkk) (2014). Land Grabbing:Bibliografi Beranotasi. Yogyakarta: STPN Press.

Gilung (2012). Talang Mamak: Hidup Terjepit di atas Tanah dan Hutannya Sendiri: Potret Konflik Kehutanan antara Masyarakat Adat Talang Mamak di kabupaten Indrairi Hulu, provinsi Riau dengan Industri Kehutanan" (Makalah, disampaikan sebagai bahan pelengkap kesaksian dalam sidang Pengujian Undang-undang No.41 tahun 1999 tentang kehutanan Terhadap undang-undang dasar negara Republik Indonesia tahun 1945 di MK RI, 14 Juni 2012.

Harto Juwono dan Yoshefine Hutagalung (2006). Tiga Tungku Sejarangan: Sejarah Kesultanan Indragiri Sampai Peristiwa 5 Januari 1949. Yogyakarta: Ombak.

Herman Hidayat (2008). Politik lingkungan: pengelolaan hutan masa Orde Baru dan reformasi.Jakarta: Yayasan Obor Indonesia.

Kang, Yoon Hee (2005). Untaian Kata Leluhur: Marjinalitas, Emosi, dan Kuasa Katakata Magi di Kalangan Orang Petalangan Riau. Pekanbaru: Pusat Penelitian Kebudayaan dan Kemasyarakatan Unri.

Kunio,Yoshihara (1990). Kapitalisme Semu di Asia Tenggara. Jakarta: LP3ES.

Kuntowijoyo (1993). Radikalisme Petani. Ygyakarta: Bentang Press Intervisi Utama.

Koentjaraningrat (dkk) (2007). Masyarakat Melayu dan Budaya Melayu dalam Perubahan Yogyakarta: Balai Kajian dan Pengembangan Budaya Melayu.

Loekman Sutrisno (1997). Kemiskinan, Perkebunan dan Transmigrasi. (Makalah, Pusat Studi Pedesaan Uiversitas Gadjah Mada, Yogyakarta).

Mardianto Manan (2009). “Bingkai-bingkai Riau”, Teraju April-Mei 2009

Mubyarto (1997). "Riau Progress and Poverty," Bijlagen tot den Taal, Land-en Volkenkunde, V.

Owen, Edgar dan Robert Shaw (1980). Pembangunan Ditinjau Kembali. Yogyakarta: Gadjah Mada University Press.

Pincus, Jonathan R. dan Jeffrey A. winters (ed) (2004). Membongkar Bank dunia. Jakarta: Jambatan.

Rencana Pembangunan Lima Tahun Keempat Daerah Tingkat I Riau, 1984.

Robinson, Dick (1982). "Struktur Kapitalisme Indonesia dan Faktor-faktor yang Mempengaruhinya”, Prisma, 1, Januari (982) 
Robison, Ricard (1986). Indonesia: The Rise of Capital. North Sydney: Allen \& Unwin, Pty Ltd.

Scott, James C (2000). Senjatanya Orang-orang Yang Kalah. Jakarta: Yayasan Obor Indonesia.

Shanin, Teodor (ed) (1971). Peasant and Peasant Societies. New York: Penguins Books.

Soedjatmoko (1984). "Dimensi-dimensi Kemiskinan Struktural", dalam Selo Soemardjan (eds). Kemiskinan Struktural. Jakarta: Yayasan Ilmu-ilmu Sosial.

Sri Margana dan M. Nursam (eds) (2010). Kota-kota di Jawa: Identitas, Gaya Hidup dan Permasalahan Sosial. Yogyakarta: Ombak.

Suhartono W. Pranoto (2001). Serpihan Budaya Feodal. Yogyakarta: Agustya Media.

Thee Kian Wie (ed) (1980). Pembangunan Ekonomi dan Pemerataan: Beberapa Pendekatan Alternatif. Jakarta: LP3ES.

(1991). Pemerataan, Kemiskinan, Ketimpangan. Jakarta: Sinar Harapan.

(2004). Pembangunan, Kebebasan dan "Mukjizat" Orde Baru.Jakarta: Penerbit Buku Kompas.

Tim Advokasi Kelapa Sawit Indonesia (2010). Fakta-fakta Kelapa Sawit Indonesia. Jakarta: Dewan Minyak Sawit Indonesia.

Yahya A. Muhaimin (1990). Bisnis dan Politik: Kebijaksanaan Ekonomi Indonesia 19501980. Jakarta: LP3ES.

Yoni Candra (2014). Mengenal Masyarakat Patalangan Batang Cenaku (Laporan Penelitian, PBHI Sumatera Barat, Padang).

Zaiyardam Zubir (2002). Radikalisme Kaum Pinggiran: Studi Tentang Issue, Strategi dan Dampak Gerakan. Yogyakarta: Insist Press. 